\title{
Nasopharyngeal Cancer Pathologic Distant Metastasis TNM Finding v6
}

National Cancer Institute

\section{Source}

National Cancer Institute. Nasopharyngeal Cancer Pathologic Distant Metastasis TNM

Finding v6. NCl Thesaurus. Code C64480.

A pathologic finding about one or more characteristics of nasopharyngeal cancer, following the rules of the TNM AJCC v6 classification system as they pertain to distant metastases. 